\title{
Education, work participation and income in Indonesia
}

\author{
Regina Niken Wilantari \\ (University Of Jember) \\ Meinarti Puspaningtyas \\ (STIE Jaya Negara Tamansiswa Malang)
}

\begin{abstract}
This study examines the relationship of education in encouraging work participation which in turn can increase the aggregate income of the people as indicated by an increase in GDP per capita in Indonesia. To achieve this goal, the Quantitative Threshold Autoregressive method is used to predict the behaviour of the data so that the behaviour of the relationship between data can be seen and can be seen the growth of community income and future work participation when investing in education is increased or done. We found that education is an important pillar in economic development. Education based on the estimation results requires a process in improving the quality of human resources and requires time in the process of increasing income. However, education can boost income and work participation in an aggregate manner so that the population can be more prosperous.
\end{abstract}

Keywords: Human Capital, Education, Income

\section{Introduction}

National Development has a close relationship with population issues related to employment (Evandrou et al,2021). Economic development is a process that causes income per capita of the population of a society to increase in the long run. One of the important goals in economic development is the provision of jobs sufficient to catch up with the growth of the workforce in developing countries, especially Indonesia where the growth of the labour force is faster, namely first, population growth in developing countries tends to be high so that it exceeds capital growth. Second, the demographic is younger so that more people enter the workforce. Third, industrial structures in developing countries tend to have low diversification of economic activity and inadequate population skills, making job creation efforts increasingly complex (Chisadza \& Bittencourt,2019).

Labour as one of the factors of production is an important and most influential element in managing and controlling the economic system, such as production, distribution, consumption and investment. Therefore, economic development A country cannot be separated from the role of humans in managing it where humans are labour, development inputs, and is also the consumption of the results of development itself, where potentially Indonesia has sufficient human resource capabilities to be developed. 
Condition the development of the workforce in Indonesia is experiencing an increase, many people work solely with various kinds of goals, but the main goal is to meet daily needs but is still there also people who have difficulty finding work, this is due to several unsupportive factors, including the level of education that does not match the expectations of the company or agency, and on the other hand, faced with various obstacles such as development number of workforce, but not followed by the availability of sufficient employment opportunities and creating participation the labour force is decreasing. Labour absorption is the number or number of people working in various sectors. The proportion of workers according to employment is one measure to see the potential of the economic sector in absorbing labour (Mason,2018).

Low levels of education usually come from households with fewer economies, so they inevitably have to participate in the labour market to help the family economy. The low level of education has an impact on the lack of job options that can be taken so that they tend to get low-paying jobs. The relationship between education and work participation in Indonesia is unidirectional or positively related, indicating that the longer schooling is, the tendency to participate in the labour market will increase with a better wage rate (Tran et al,2019).

This study examines the relationship of education in encouraging work participation which in turn can increase the aggregate income of the society as indicated by an increase in GDP per capita in Indonesia. When education as a form of human capital investment to improve the skills and knowledge of the community increases, the quality of human resources or the population or community members who enter the productive age has increased quality and should get a job with a better wage rate. So that when human capital or the quality of human resources increases, aggregate income will also increase.

\section{Literature Review}

The development of education and health are two pillars to form human capital in economic development which is nothing but a long-term investment in a country. Achieving the goals of development in the fields of education and health, in turn, can improve the quality and productivity of the population, where population productivity growth is the motor of economic growth and the welfare of the population itself. Through investment in education, it will be able to improve the quality of human resources as shown by the increase in knowledge and skills which will encourage an increase in one's work productivity, and in the end, someone who has high productivity will get better welfare and avoid poverty (Ogundari \& Awokuse,2018).

The magnitude of the labour force participation rate to work in the labour market is influenced by general factors, namely the level of economic poverty and the limitations of the husband to meet the needs of his family. The insufficient dependence of life on the part of men encourages a person to offer himself in the labour market. In addition to the general factors above, the increase in women's participation in economic activities can be largely due to three things that are interrelated. First, the available productive employment is increasing, which is closely related to economic development and support for mastery of science and technology as well as market expansion due to the increasing demand for goods and services. Second, there are more job opportunities that are more suitable for the type of work done. This is closely related to success in the fields of education, health and family planning programs as well as changes in people's views about working for the community. Third, the development as a whole has increased the needs of society both material and immaterial, thus 
encouraging people to fulfil the job market to meet these needs, both individually and in families (Cairó et al,2021).

A household is said to be poor if its consumption does not meet the minimum needs for food and non-food, meaning that the income earned by working family members is not sufficient for consumption by the dependent family members. If the income level is small, while the number of people to bear is large, it means that most of the portion of income is for consumption, while the portion for saving is very small and even does not result in very low capital formation in poor households so that opportunities to improve their standard of living are also very limited. Poverty is not only a matter of income but is related to the capabilities that a person must have, in this case, one of which is related to the problem of access, both to education, health and job opportunities. Thus the handling of poverty will be more comprehensive. In order to change economic backwardness and generate capacity and motivation to progress, it is important to increase the knowledge and skills of the people (VOS \& CATTANEO,2021).

In reality, without improving the quality of the human factor, progress will not be possible. So, it can be seen that the country is poor because it has an unqualified population. Even though physical construction is carried out such as roads, factories, hospitals, and so on, the people who are not of quality physical capital cannot be utilized properly. Many poor people experience ignorance or experience ignorance even systematically. Therefore, it is important for us to understand that poverty can lead to ignorance, and ignorance is clearly synonymous with poverty. To break the chain of cause and effect above, there is one key element, namely education. Because education is a means of eliminating ignorance as well as poverty. The supply or supply of manpower contains an understanding of the number of residents who are currently and ready to work as well as an understanding of the quality of the work effort provided. In general, labour supply is influenced by several factors such as population, number of workers, number of hours worked, productivity education and others. For the effect of population size and age structure, the more the population is under the age of children, the smaller the number that is classified as a workforce (Liang \& Lu,2019).

\section{Research Methods and Materials}

This study examines the relationship of education in encouraging work participation which in turn can increase the aggregate income of the people as indicated by an increase in GDP per capita in Indonesia. To achieve this goal, the Quantitative Threshold Autoregressive method is used to predict the behaviour of the data so that the behaviour of the relationship between data can be seen and can be seen the growth of community income and future work participation when investing in education is increased or done. The hope is that knowing past behaviour data can be an indicator of decisions that can be taken. in the future. In this study we used the autoregressive equation as follows:

$\mathrm{AR}_{(\mathrm{p})}=\mathrm{Y}_{\mathrm{t}}=\mathrm{c}+\Phi_{1} \mathrm{Y}_{\mathrm{t}-1}+\Phi_{2} \mathrm{Y}_{\mathrm{t}-2}+\ldots \ldots+\Phi_{\mathrm{p}} \mathrm{Y}_{\mathrm{t}-\mathrm{p}}+\mathrm{e}_{\mathrm{t}}$

Where AR is $\mathrm{Y}$ and $\mathrm{Yt}$ is $\mathrm{Y}$ over time in a time series which is influenced by Yt-1 or Y over time in the past in period 1 and Yt-1 itself is also influenced by Yt-2 which is $\mathrm{Y}$ in the past in the period 2 and so on which is influenced by et which is the error term for the time in the study period. This study focuses on secondary data sourced from the world bank including Indonesia gross domestic product per capita data, education investment in Indonesia and work participation in Indonesia. With the econometric equation as follows: 
$\mathrm{Y}_{\mathrm{t}}=\beta_{0}+\beta_{1} \mathrm{P}_{\mathrm{t} 1}+\beta_{2} \mathrm{E}_{\mathrm{t} 2}+\mathrm{e}_{\mathrm{t}}$

Where $\mathrm{Y}$ is a gross domestic product per capita, $\mathrm{t}$ is a time period, $\beta$ is constant, $\mathrm{P}$ is work participation, $\mathrm{E}$ is education investment, and $\mathrm{e}$ is error term. All data are secondary data from world banks.

\section{Results and Discussion}

To see behavioural data from education investment, work participation and community income, an autoregressive threshold estimate was carried out. The following are the estimation results that we have done:

GDP_PER_CAPITA $=(3.43783350201 \mathrm{e}-08 *$ EDUCATION $+2.11640088557 \mathrm{e}-05 *$ PARTICIPATION $-1641.31331143)+(4.72063775944 \mathrm{e}-09 *$ EDUCATION $-3.16118975882 \mathrm{e}-05 *$ PARTICIPATION + 3355.36404417)*@LOGIT(0.0198586502554*(GDP_PER_CAPITA(-3)-3163.02801121))

The estimation results from the first estimate can be seen in table 1 below:

Table 1. Estimation Result

\begin{tabular}{|c|c|c|c|c|}
\hline Variable & Coefficient & Std. Error & t-Statistic & Prob. \\
\hline \multicolumn{5}{|c|}{ Threshold Variables (linear part) } \\
\hline EDUCATION & $3.44 \mathrm{E}-08$ & $1.08 \mathrm{E}-08$ & 3.185474 & 0.0129 \\
\hline PARTICIPATION & $2.12 \mathrm{E}-05$ & 7.40E-06 & 2.860997 & 0.0211 \\
\hline $\mathrm{C}$ & -1641.313 & 714.9914 & -2.295571 & 0.0508 \\
\hline \multicolumn{5}{|c|}{ Threshold Variables (nonlinear part) } \\
\hline EDUCATION & $4.72 \mathrm{E}-09$ & $2.13 \mathrm{E}-08$ & 0.221696 & 0.8301 \\
\hline PARTICIPATION & $-3.16 \mathrm{E}-05$ & $2.46 \mathrm{E}-05$ & -1.285463 & 0.2346 \\
\hline $\mathrm{C}$ & 3355.364 & 2415.691 & 1.388987 & 0.2023 \\
\hline SLOPE & 0.019859 & 0.013844 & 1.43445 & 0.1894 \\
\hline \multicolumn{5}{|l|}{ Thresholds } \\
\hline THRESHOLD & 3163.028 & 38.84224 & 81.43269 & 0 \\
\hline R-squared & 0.999093 & Mean dependent var & & 2805.471 \\
\hline Adjusted R-squared & 0.998186 & S.D. dependent var & & 1084.888 \\
\hline S.E. of regression & 46.21174 & Akaike info criterion & & 10.8094 \\
\hline Sum squared resid & 17084.2 & Schwarz criterion & & 11.25051 \\
\hline Log likelihood & -82.87987 & Hannan-Quinn criter. & & 10.85324 \\
\hline F-statistic & 1101.287 & Durbin-Watson stat & & 2.673851 \\
\hline Prob(F-statistic) & 0 & & & \\
\hline
\end{tabular}

Source : Data world Bank Compiled

It can be seen that the per capita GDP relationship to education and work participation is positive with a value of $3.44 \mathrm{E}-08$ for education and $2.12 \mathrm{E}-05$ for work participation, which means an increase in 
education investment of $3.4 \%$ is followed by an increase in work participation of $2.12 \%$ and encourages average income in the community by $1 \%$ which is indicated by an increase in GDP per capita. This shows that investment in education can boost people's income in general. However, in the non-linear estimation, the relationship between work participation and community income is negative at $-3.16 \mathrm{E}-05$ and education investment is 4.72E-09. This indicates that an increase in income can encourage investment in education. When investment in education is made, the population goes to school so that work participation decreases. The greater the investment in education in the education investment process, of course, it takes time, in this process, there is a decrease in work participation. However, after the education investment process is complete, an increase in work participation will follow, followed by an increase in wages, according to a non-linear estimate. To determine the behaviour of data in influencing economic growth, predictions of the effect of investment in education, health and technology can be made in the following graph:

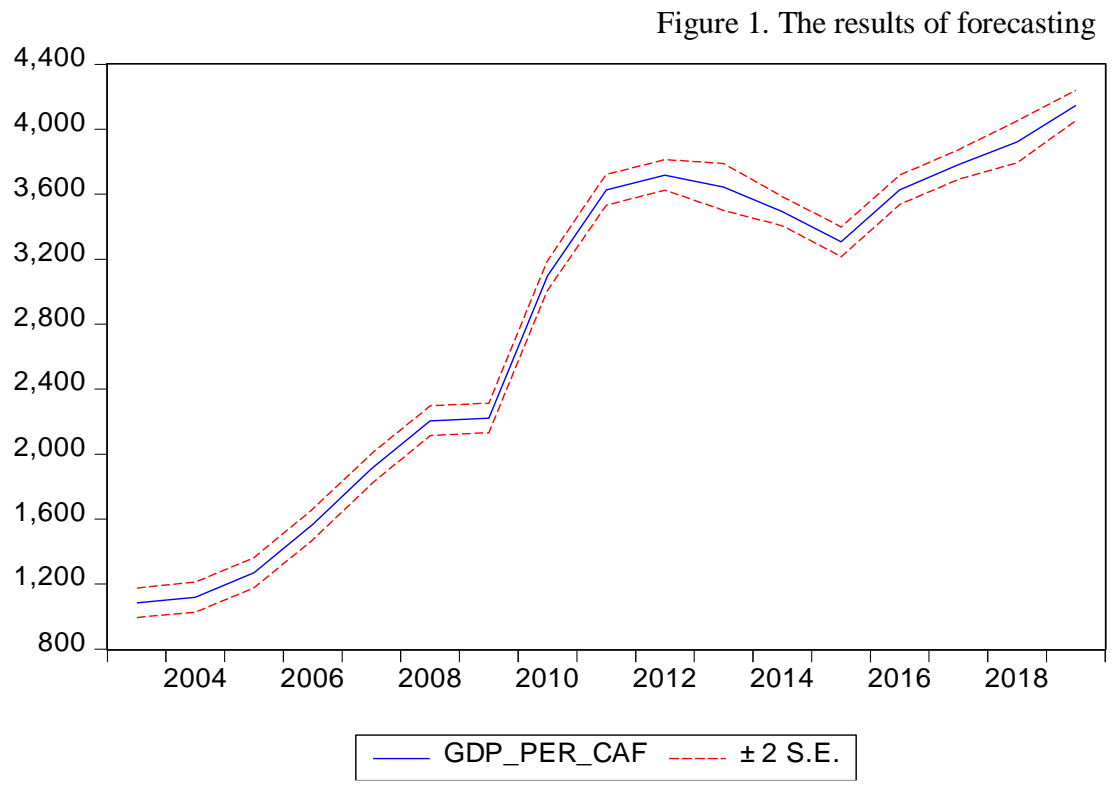

$\begin{array}{ll}\text { Forecast: GDP_PER_CAF } \\ \text { Actual: GDP_PER_CAPITA } \\ \text { Forecast sample: } 20002019 \\ \text { Adjusted sample: } 20032019 \\ \text { Included observations: } 17 \\ \text { Root Mean Squared Error } & 32.59504 \\ \text { Mean Absolute Error } & 28.00931 \\ \text { Mean Abs. Percent Error } & 1.175750 \\ \text { Theil Inequality Coefficient } & 0.005436 \\ \quad \text { Bias Proportion } & 0.006494 \\ \text { Variance Proportion } & 0.003227 \\ \quad \text { Covariance Proportion } & 0.990279 \\ \text { Theil U2 Coefficient } & 0.108418 \\ \text { Symmetric MAPE } & 1.175210\end{array}$

Source : Data world Bank Compiled

From the forecast results shown in Figure 1, it can be seen that the GDP per capita graph tends to increase over time and fluctuate. These fluctuations represent fluctuations in the education process and fluctuations in work participation as a result of educational investment. But in the end, it will boost the community's income in aggregate so that the people's welfare can be better.

\section{Conclusions}

Education is an important pillar in economic development. Education based on the estimation results requires a process in improving the quality of human resources and requires time in the process of increasing income. However, education can boost income and work participation in an aggregate manner so that the population can be more prosperous. 


\section{References}

Cairó,I., Fujita,S., Morales-Jiménez,C.(2021).The cyclicality of labor force participation flows: The role of labor supply elasticities and wage rigidity.Review of Economic Dynamics, 10(2),1-9.https://doi.org/10.1016/j.red.2021.02.001

Chisadza,C., Bittencourt,M.(2019).Economic development and democracy: The modernization hypothesis in sub-Saharan Africa.The Social Science Journal,56(2),243-254.https://doi.org/10.1016/j.soscij.2018.10.007

Evandrou,M., Falkingham,J., Qin,M., Vlachantoni,A.(2021).Menopausal transition and change in employment: Evidence from the National Child Development Study.Maturitas,142(1),96-104.https://doi.org/10.1016/j.maturitas.2020.09.010

Liang,W., Lu,M.(2019).Growth led by human capital in big cities: Exploring complementarities and spatial agglomeration of the workforce with various skills.China Economic Review,57(10),1-9.https://doi.org/10.1016/j.chieco.2017.09.012

Mason,J.(2018).Entrepreneurship in knowledge-based services: Opportunity and challenges for new venture, economic, and workforce development.Journal of Business Venturing Insights,10(11),1-9.https://doi.org/10.1016/j.jbvi.2018.e00092

Ogundari,K., Awokuse,T.(2018).Human capital contribution to economic growth in Sub-Saharan Africa: Does health status matter more than education?.Economic Analysis and Policy,58(6),131-140.https://doi.org/10.1016/j.eap.2018.02.001

Tran,T.Q., Pham,H.H., Vo,H.T., Luu,H.T., Nguyen,H.M.(2019).Local governance, education and occupation-education mismatch: Heterogeneous effects on wages in a lower middle income economy.International Journal of Educational Development,71(11).1-9. https://doi.org/10.1016/j.ijedudev.2019.102101

VOS,R., CATTANEO,A.(2021).Poverty reduction through the development of inclusive food value chains.Journal of Integrative

Agriculture,20(4),964-978. https://doi.org/10.1016/S2095-3119(20)63398-6 